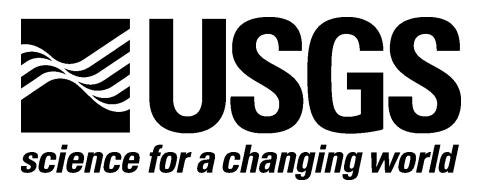

Prepared for the U.S. Environmental Protection Agency in Cooperation with U.S. EPA National Enforcement Investigations Center

\title{
Particle Size Characterization of Water-Elutriated Libby Amphibole 2000 and RTI International Amosite
}

By Heather A. Lowers and Amy M. Bern

Open-File Report 2009-1242

U.S. Department of the Interior

U.S. Geological Survey 


\section{U.S. Department of the Interior \\ Ken Salazar, Secretary}

\section{U.S. Geological Survey \\ Suzette M. Kimball, Acting Director}

U.S. Geological Survey, Reston, Virginia: 2009

For product and ordering information:

World Wide Web: http://www.usgs.gov/pubprod

Telephone: 1-888-ASK-USGS

For more information on the USGS-the Federal source for science about the Earth,

its natural and living resources, natural hazards, and the environment:

World Wide Web: http://www.usgs.gov

Telephone: 1-888-ASK-USGS

Suggested citation:

Lowers, H.A., and Bern, A.M, 2009, Particle size characterization of water-elutriated Libby amphibole 2000 and RTI international amosite: U.S. Geological Survey Open-File Report 2009-1242, 3 p.

Any use of trade, product, or firm names is for descriptive purposes only and does not imply endorsement by the U.S. Government.

Although this report is in the public domain, permission must be secured from the individual copyright owners to reproduce any copyrighted material contained within this report. 


\section{Contents}

Introduction.

Explanation of Excel Worksheets.

Reference Cited 


\title{
Particle Size Characterization of Water-Elutriated Libby Amphibole 2000 and RTI International Amosite
}

\author{
By Heather A. Lowers and Amy M. Bern
}

\section{Introduction}

This report presents data on particle characterization analyzed by scanning electron microscopy on Libby amphibole collected by the U.S. Geological Survey in 2000 (LA2000) and amosite material collected by RTI International (RTI amosite). The particle characterization data were generated to support a portion of the Libby Action Plan. Prior to analysis, the raw LA2000 and RTI amosite materials were subjected to a preparation step. Each sample was water-elutriated by U.S. Environmental Protection Agency (USEPA) Office of Research and Development, Research Triangle Park using the methods generally described in Webber and others (2008) and then delivered to the U.S. Geological Survey, Denver Microbeam Laboratory for analysis. Data presented here represent analyses performed by the U.S. Geological Survey, Denver Microbeam Laboratory and USEPA National Enforcement Investigations Center.

This report consists of two Excel spreadsheet files developed by USEPA, Region 8 Superfund Technical Assistance Unit. The two Excel files are labeled USGS_NEIC_LA2000_SEM_100509_top_right.xls and USGS_NEIC_RTI_Amosite_SEM_100509_top_right.xls and describe the particle size characterization of the LA2 $\overline{0} 00$ and RTI amosite, respectively. Multiple tabs and data entry cells exist in each spreadsheet and are defined herein.

\section{Explanation of Excel Worksheets}

The worksheets within the file and data entry cells within each worksheet are described.

- Sample: This worksheet summarizes the sample identification and instrument parameters.

○ Magnification: the magnification of each field of view (FOV).

- FOV Area: the area in square millimeters of the field of view analyzed by each laboratory. Note the area of the FOV analyzed by each laboratory is different.

- Min Width and Min Length: all particles were analyzed regardless of size (min, minimum).

- Min Aspect Ratio: this value is greater than or equal to one for all analyses.

- Prep: This worksheet summarizes sample preparation of the dried water-elutriated materials (LA2000 and RTI amosite) and effective loading of the filter.

○ Sample mass suspended $(\mathrm{g})$ : weight of material in grams $(\mathrm{g})$ that was put into the suspension from which an aliquot was collected. 
- Suspension volume $(\mathrm{mL})$ : volume of deionized water in milliliters of the suspension.

- Volume applied to filter $(\mathrm{mL})$ : volume of aliquot in milliliters removed from the suspension and filtered.

- Effective Filter Area $\left(\mathrm{mm}^{2}\right)$ : area of the filter in square millimeters covered by the sample.

- Filter Loading $\left(\mathrm{ug} / \mathrm{mm}^{2}\right)$ : mass in micrograms per square millimeter on the filter.

○ No matrix enrichment was performed.

- 1000 Structure Count: This worksheet summarizes the total particle characterization within the analyzed fields of view. Particles that extended beyond the field of view on the left or bottom edge have been omitted.

- Field of View (FOV) ID: identification number for each field of view analyzed at 2,000x.

- Structure Index No.: total running tally of particles analyzed across fields of view.

- Type: particles with aspect ratio (length divided by width) greater than 3 were labeled fiber, and those with aspect ratio less than three were labeled nonfiber regardless of phase identification. The approach of describing a particle with aspect ratio 3 or greater as a fiber is a current analytical convention and does not inform anything about potential toxicity of the particle.

- Length: the length in micrometers as measured parallel to the longest side of the particle.

- Width: the average width in micrometers as measured perpendicular to the length.

- Aspect Ratio Field: value of the length divided by the width.

- Morphology: this field describes special attributes of the particles such as stepped, single fiber (SF), blocky, tapered, splayed, curved, platey, scrolled, bladed, conchoidal, fractured, matrix, sphere, and bundle.

- Mineral Class: mineral analyzed (LA, Libby amphibole).

- Photo ID: filename for the image in which the particle was measured.

- Spectrum ID: filename for the spectrum of the particle, if saved.

- Structure Comments: any additional information not covered in the previous columns. For example magnification used to measure the length of the particle if not measured at 5,000x or additional information regarding the chemistry of the Libby amphibole.

- Lab Name: identification of the lab that measured the particle

- Analyst Name: laboratory personnel who recorded the particle measurements.

- Addt'l Structures L $>5 \mu \mathrm{m}$ : This worksheet summarizes the characterization of particles greater than five micrometers long only within each additional field of view analyzed. Columns are defined as in the previous tab. 


\section{Reference Cited}

Webber, J.S., Blake, D.J., Ward, T.J., and Pfau, J.C., 2008, Separation and characterization of respirable amphibole fibers from Libby, Montana: Inhalation Toxicology, v. 20, no. 8, p. 733740. 